Kochetova T. I., Associate Professor of the Department of International Business and Finance; ORCID: 0000-00015273-5066; (+38) 098- 429-07-78; E-mail: kocheti.tat@gmail.com.

Sovgir A. I., student, (+38)098- 787-82-34; E-mail: sovgir2001@gmail.com

National Technical University "Kharkiv Polytechnic Institute", Kharkiv, Ukraine, Kyrpychova str., 2, 61002

\title{
SECURITY MARKET UNDER CONDITIONS OF COVID-19
}

\begin{abstract}
The article is devoted to the analysis of the state of the international securities market during a pandemic. The fundamentals of the functioning of the securities market, technologies for conducting various transactions with securities during the quarantine period associated with the Covid-19 epidemic are considered. The results of the impact of the COVID-19 pandemic on the global economy at the end of 2020 were reviewed. The study uses an analytical approach based on the analysis of global statistics on COVID-19. The main negative trends of the modern world economy caused by the increase in economic costs under the influence of the spread of the COVID-19 pandemic are summarized. The study used demographic indicators of the countries of the world, data on the dynamics of oil prices, stock indices, and statistical data on world trade. Based on the analysis of economic policy measures taken in the leading countries of the world to smooth out the negative consequences of the spread of the global COVID-19 pandemic, proposals were formulated for the economic policy of conducting operations in the securities market in the context of the COVID-19 pandemic.
\end{abstract}

Keywords: coronavirus, global stock market, global economy, world dependence, pandemic, world prices, financial crisis.

Кочетова Тетяна Іванівна, доцент кафедри міжнародного бізнесу та фінансів, ORCID: 0000-0001-52735066. Тел. (+38) 098- 429-07-78; E-mail: kocheti.tat@gmail.com.

Совгір Анастасія Ігорівна, студентка, Тел. (+38)098- 787-82-34; E-mail: sovgir2001@gmail.com

Національний технічний університет «Харківський політехнічний інститут», вул. Кирпичова, 2, Харків, Украӥна, 61002.

\section{РИНОК ЦІННИХ ПАПЕРІВ В УМОВАХ COVID-19}

\begin{abstract}
Анотація. Стаття присвячена аналізу стану міжнародного ринку иінних паперів в період пандемії. Розглянуто основи функціонування ринку цінних паперів, технології проведення різних операцій з цінними паперами в період карантину, пов'язаного з епідемією Соvid -19. Розглянуто результати впливу пандемії COVID-19 на світову економіку в кіниі 2020 року. У дослідженні використано аналітичний підхід, заснований на аналізі світової статистики по COVID-19. Узагальнено основні негативні тендениії сучасної світової економіки, викликані зростанням економічних витрат під впливом поширення пандемії COVID-19. В рамках дослідження використовувалися демографічні показники країн світу, дані про динаміку цін на нафту, фондові індекси, статистичні дані по світовому товарообігу. На основі аналізу заходів економічної політики, прийнятих у провідних краӥнах світу для згладжування негативних наслідків поширення глобальної пандемї COVID-19, сформульовані пропозицї щзоо економічної політики проведення операцій на ринку цінних паперів в контексті пандемії COVID-19.
\end{abstract}

Ключові слова: коронавірус, світовий фондовий ринок, глобальна економіка, світова залежність, пандемія, світові иүіни, фінансова криза.

Кочетова Тетяна Іванівна, доцент кафедри міжнародного бізнесу та фінансів; ORCID: 0000-0001-52735066; тел. (+38) 098- 429-07-78; E-mail: kocheti.tat@gmail.com.

Совгір Анастасія Ігорівна, студентка, тел. (+38)098- 787-82-34; E-mail: sovgir2001@gmail.com

Національний технічний університет «Харківський політехнічний інститут», вул. Кирпичова, 2, Харків, Украӥна, 61002.

\section{РЫНОК ЦЕННЫХ БУМАГ В УСЛОВИЯХ СОVID-19}

\begin{abstract}
Анотация. Статья посвящена анализу состояния международного рынка ценных бумаг в период пандемии. Рассмотрены основы функиионирования рынка ценных бумаг, технологии проведения различных операций с ценными бумагами в период карантина, связанного с эпидемией Cоvid -19. Рассмотрены результаты воздействия пандемии COVID-19 на мировую экономику в конще 2020 года. В исследовании использован
\end{abstract}


аналитический подход, основанный на анализе мировой статистики по COVID-19. Обобщень основные негативные тенденции современной мировой экономики, вызванные возрастанием экономических издержек под влиянием распространения пандемии COVID-19. В рамках исследования использовались демографические показатели стран мира, данные о динамике цен на нефть, фондовые индексы, статистические данные о мировом товарообороте. На основе анализа мер экономической политики, принимаемых в ведущих странах мира для сглаживания негативньх последствий распространения глобальной пандемии COVID-19, сформулировань предложения по экономической политике проведения операций на рынке ценных бумаг в контексте пандемии COVID-19.

Ключевые слова: коронавирус, мировой фондовый рынок, мировая экономика, мировая зависимость, пандемия, мировые ичены, финансовый кризис.

Introduction. The majority of people turn to the performance of a country's stock market as the best indicator of how well that economy is doing. Stock markets cover all industries across all sectors of the economy. This means they serve as a barometer of what cycle the economy is in and the hopes and fears of the population who generate growth and wealth. For investors, stock markets provide a way to invest money in order to potentially earn a share of the company's profits (knowing that the risk of losses exists too). Active investors and traders can easily buy and sell their securities due to the abundant liquidity in most major stock markets.

It is no secret about the current situation in the world - the pandemic has touched everyone, including the financial parts of our world. The specificity of stock markets is that they are not a mirror image of the state of the economy. The peaks of the indices usually happen just before the start of the recession, and the reversal can happen well in advance, before the economy has even begun to recover. Investors' expectations are incorporated into the share price; quotes are very sensitive to the news background.

The flow of negative information related to COVID-19 has become habitual during the quarantine. People try to get something out of it that at least partially resembles a positive and, probably, overestimate the importance of positive factors.

Formulation of the problem. The relevance is due to the fact that at the present stage, the development of the stock market is one of the key tasks of states in stimulating socioeconomic progress. Also, the relevance of the study lies in the fact that today there is a reversal of trends in the securities market, which may mean the formation of a financial crisis. First of all, this is due to the impact of the coronavirus pandemic on the economic situation in the world. Within the framework of the article, a technical analysis of the dynamics of stock indices is carried out in order to determine the current trends in the development of the world stock market. The most pressing problems of the current stage of the functioning of the securities market are listed. In view of their presence, barriers are created. In the results of the article, it was found that the main trend of the coronavirus pandemic had a negative impact on the meaning of the global stock market, leading to a fall in the value and market capitalization of financial assets.

Purpose's formulation of the article. Analyse the impact of the COVID-19 pandemic on the global economy. To achieve this goal, a huge amount of international statistical data on COVID-19 was used, as well as data reflecting the main demographic trends in the countries of the world in 2019-2020, in particular, information on population and mortality. To assess the impact of COVID-19 on oil-dependent countries, the current information on the dynamics of oil prices on world markets was analysed. Major indices reflecting the state of affairs in the global stock markets were used to determine the impact of COVID-19 on the global financial market.

Main part. Stock markets have existed for centuries and will no doubt go on being the main public, regulated marketplaces where people can buy and sell shares of different companies. It is a designated market for trading various kinds of securities in a controlled, secure 
and managed environment. Since the stock market brings together hundreds of thousands of market participants who wish to buy and sell shares, it ensures fair pricing practices and transparency in transactions.

Stock markets enable companies to be traded publicly and raise capital. The transfer of capital and ownership is traded in a regulated, secure environment. Stock markets promote investment. The raising of capital allows companies to grow their businesses, expand operations and create jobs in the economy. This investment is a key driver for economic trade, growth and prosperity.

Stock markets are vital components of a free-market economy because they enable democratized access to trading and exchange of capital for investors of all kinds. They perform several functions in markets, including efficient price discovery and efficient dealing. occurred.

Due to the spread of Covid-19 on the securities market, the following changes have

American and European stock indexes have fallen from their highs of February 19 by $12-$ $15 \%$, many Asian markets sank heavily, as well as Russia, due to fears that the coronavirus pandemic spreading around the world will undermine the economy, business and corporate profits. But there are some bright spots against the overall dark backdrop. Investors are investing in the securities of health care organizations, as well as the stocks of companies that would benefit if thousands or even millions of people were quarantined in their homes.

Surprisingly, the stock market in the country where the coronavirus outbreak began China - is doing well. The CSI 300 Index, which includes stocks of leading companies from the Shanghai and Shenzhen stock exchanges, is now above where it was before the lunar New Year vacation, from which millions of Chinese did not return to work.

Campbell Soup shares gained 10 percent on March 4, their strongest daily gain in two decades, the Financial Times noted. Over the next two days, the stock declined slightly from its gains, though the S\&P 500 Index fell 5 percent. Campbell Soup shares are up 8.4\% since Feb. 19, while the S\&P 500 has lost more than 12\%. During the same time, shares of U.S. home improvement chain Kroger have gained 8.5\%, disinfectant wipes maker Clorox has gained 5.2\%, and video game developer Electronic Arts and video service Netflix are down 2-4\%, which can also be considered an achievement amid the market crash. Shares of Kimberly-Clark, which makes, among other things, nursing wear and hygiene supplies, fell with the entire market in February, but soared to a new all-time high in March. [1]

All of these papers are involved in a "coronautrade," says Leuthold Group chief market strategist Jim Paulsen (his words cited by the FT): people are shopping for groceries and video games in case they have to stay home. Coronavirus has made it more likely that "consumers will stock up on soup and eat at home more often than usual," JPMorgan Chase analysts wrote in a report. [2]

After an initial nervous reaction, gold stocks began to recover quickly. There is no reason for gold prices to fall, given not only its safe-haven status, but also easing monetary and fiscal policies around the world that further increase liquidity and lead to competing currency devaluations, says Jon Treacy, publisher of investment newsletter Fuller Treacy Money. [3]

At the end of February, the price of gold, and gold stocks followed, plummeted. By selling them, investors plugged the holes in their portfolios created by the stock market crash, explains Treacy. This week not only did gold recoup all of its losses, but it went up $\$ 1690$ a troy ounce (closing Friday at $\$ 1673.8$ versus $\$ 1611.7$ an ounce on Feb. 19). 
Shares of biotech and pharmaceutical companies, especially those that could provide a vaccine or drug to fight the coronavirus, also benefited. Inovio Pharmaceuticals jumped after it announced on March 3 that it was accelerating the development of a vaccine against coronavirus and expected to start clinical tests in the U.S. in April. Its stock rose $70 \%$ that day, another $7.8 \%$ on March 4, and $22.1 \%$ on March 5. In just the past three months, its shares have more than tripled. The Chinese market has been the best performer since the beginning of February. After opening on February 3 after the New Year vacations with a 9\% drop, the CSI 300 Index has since gained $13.7 \%$. On February 5, it even closed at its highest level since the beginning of 2018 [4].

The rate of coronavirus infections has been falling in China since early February. The death rate, according to the latest statistics, has fallen to $1 \%$ versus $3-4 \%$ at the height of the epidemic in the country and outside of China now, Yong Trisi points out. The stock market is also supported, he says, by stimulus measures by the authorities, such as the ban on bankruptcies, the extension of bond maturities and excess liquidity. The market is unlikely to continue to rise strongly given the uncertain global environment, "but it is no doubt showing relative strength," says Treacy. International investors are also likely to have supported the rise in Chinese equities, hoping that China will be the first to get out of the crisis, he believes. [5]

What should we do as an investor?

1.It depends on what kind of investor you are (short-term or long-term, risk-averse, risktolerant, etc.). But during these volatile periods, it's always a good idea to review your investments and make sure you have good risk diversification.

2.For short-term or more anxious investors, it may be worthwhile to review their risks and, if necessary, reduce risk.

3.The long-term and/or risk-tolerant investor should not take any action, except perhaps to monitor buying opportunities in the coming weeks.

Amid the outbreak of a new disease, investors have revised their views on the future of the global economy. The restrictive measures introduced in different countries have negatively affected almost all industries related to consumer activity: tourism, trade, catering, entertainment and others. Under quarantine, people spend and move less.Bidders began to get rid of shares in airlines, oil companies, consumer electronics manufacturers and other companies, expecting a drop in revenues and revenues. The indices of the world's leading stock exchanges have collapsed. The Italian FTSE MIB index alone lost 29.8\% from February 19 to March 11. [6]

Interestingly, the Chinese stock market began to gradually recover, while in other countries it continued to fall. For clarity - the charts of the American S\&P 500 index and the Chinese Shanghai Composite.According to the forecast of Oxford Economics, the coronavirus epidemic will slow down the growth rate of world GDP from $2.6 \%$ to $1 \%$ and "take away" at least \$ 1.1 trillion. Against the background of an already stagnating economy, a recession may begin, and after that - a global crisis. The coronavirus is inferior to swine flu in terms of the number of infected, but it is significantly ahead in the number of deaths. In terms of the level of impact on the global economy, COVID-2019 is already not inferior to swine flu, while the spread of the disease is still continuing. In addition, the virus for the first time in history had a strong negative impact on stock market quotes, dropping the S \& P500 index by $13 \%$. [7]

Uncertainty remains about the future development of the COVID-19 situation. It is one of the main driving forces in the increasingly volatile stock markets. The movement of quotations actually depends on the development of the situation with the pandemic. Different scenarios of how the situation with the coronavirus will develop and how it will affect the markets, several consulting agencies and investment banks have already outlined - in particular, McKinsey did it in March. 
McKinsey says the coronavirus outbreak will put the greatest strain on health care systems in the US, Europe and elsewhere, but will slow as the warmer approaches. The authorities will have to take increasingly aggressive steps, which will cause a slowdown in economic growth, which will continue throughout the second quarter. Some industries, such as air travel and hospitality, will be hit hard. The global economy will avoid recession and recover in the second half of the year. However, global economic growth will halve to $1-1.5 \%$. The US economy will grow by less than $1 \%$ on a year, and China's GDP will grow by less than $4 \%$. [8]

Morgan Stanley and UBS. Morgan Stanley says its interim scenario is to peak incidence by the end of May. This will entail a slowdown in US economic growth in the second quarter and a recovery in the second half of the year. Global economic growth in the first half of 2021 will be $2.3 \%$, but will accelerate in the second half of the year. Despite the economic consequences, the outlook for the stock market is not so bad - according to investment director Mike Wilson, the market will freeze " in limbo between bulls and bears", but will remain ready for a rally. Morgan Stanley assessed this scenario as "the most plausible." [9]

UBS warns that if the number of infected increases significantly, the bank predicts more than 100 million infections worldwide and 1 million in the United States. The situation will be brought under control in the middle of the year, but the US, Europe and Japan will fall into recession, after which their economies will return to rapid growth in the fourth quarter. The global economy will recover at an accelerated rate until China suffers from relapse of coronavirus. Markets could fall $25 \%$ from their highs before regaining the decline - by the end of the year they will fall by $3 \%$. [10]

Conclusions. The analysis of the impact of the COVID-19 pandemic on the global economy allows us to draw the following conclusions: COVID-19, which has spread to more than 200 countries, has enormous consequences for the economies of both individual countries and the whole world. Public policies in individual countries to smooth out the economic costs of a pandemic could have significant negative consequences in the long term.

The COVID-19 outbreak has created imbalances in the global economy due to supply chain disruptions resulting from production closures in China. The virus has spread throughout the world, with the United States having the highest number of cases and deaths. The pandemic caused a major collapse in oil prices, the largest since the 1991 Gulf War. In addition, this endangered the economies of oil-dependent countries. The quarantine measures introduced by countries to smooth out the spread of the pandemic, such as quarantine, self-isolation, restrictions on international and local travel and trade, etc., continue negatively impact the global economic situation. The economic impact of COVID-19 is likely to be less than the impact of the tough policy measures taken to prevent the spread of the virus. Because of the pandemic, global stock markets recorded their largest and sharpest drop since the 2008 global financial crisis.

At the political level, coordinated action by all countries will be required to implement a medical protocol to reduce the spread of the pandemic, as well as fiscal measures to support the manufacturing sector to accelerate economic recovery. This will require additional measures to support consumers, restore purchasing power and help businesses. Such measures may include lowering the discount rate by central banks (taking into account the experience of the United States) in order to expand access to credit resources and stimulate investment activity. Another measure can be a reduction in the tax burden on businesses and the population. However, only time will tell whether governments will agree to these measures. 


\section{Гписок використаної літератури:}

1. Official data: Campbell Soup Company. URL: https:/finance.yahoo.com/quote/CPB/

2. Official data: Jim Paulson. URL: https://www.ft.com/stream/46fa5c37-9097-4d2d-8c40-8fec0396aa1d

3. Official data: Investment newsletter Fuller Treacy Money. URL: http:/www.fullertreacymoney.com/investment-themes/?search=Technology

19/

4. Official data: official website Inovio. URL: https://www.inovio.com/our-focus-serving-patients/covid-

5. Official data: newsletter Yong Trisi. URL: https://youngminds.org.uk/about-us/reports/coronavirusimpact-on-young-people-with-mental-health-needs/

6. Official data: Italy Stock Market (FTSE MIB). URL: https://radingeconomics.com/italy/stock-market

7. Official website: Oxford Economics. URL: https://www.oxfordeconomics.com

8. Official website: McKinsey company. URL: https://www.mckinsey.com/mgi/overview\# do/research

9. Official website: Morgan Stanley company. URL: https://www.morganstanley.com/what-we-

10. Official website: UBC company. URL: https://www.ubs.com/global/en/our-firm/what-wedo/research.html

\section{References:}

1. Official data: Campbell Soup Company. Available at: https://finance.yahoo.com/quote/CPB/

2. Official data: Jim Paulson. Available at: https://www.ft.com/stream/46fa5c37-9097-4d2d-8c408fec0396aald

3. Official data: Investment newsletter Fuller Treacy Money. Available at: http://www.fullertreacymoney.com/investment-themes/?search=Technology

4. Official data: official website Inovio. Available at: https://www.inovio.com/our-focus-servingpatients/covid-19/

5. Official data: newsletter Yong Trisi. Available at: https://youngminds.org.uk/aboutus/reports/coronavirus-impact-on-young-people-with-mental-health-needs/ market

6. Official data: Italy Stock Market (FTSE MIB). Available at: https://tradingeconomics.com/italy/stock-

7. Official website: Oxford Economics. Available at: https://www.oxfordeconomics.com

8. Official website: McKinsey company. Available at: https://www.mckinsey.com/mgi/overview\# do/research

9. Official website: Morgan Stanley company. Available at: https:/www.morganstanley.com/what-we-

10. Official website: UBC company. Available at: https://www.ubs.com/global/en/our-firm/what-wedo/research.html 